\title{
Comparative analysis of the geographic distribution of the histopathological spectrum and Leishmania species of American cutaneous leishmaniasis in Brazil ${ }^{*}$
}

\author{
Análise comparativa da distribuição geográfica do espectro histopatológico e \\ espécies de Leishmania da leishmaniose tegumentar americana no Brasil
}

\author{
Linton Wallis Figueiredo Souza ${ }^{1}$ \\ Ana Cristina Carvalho Botelho ${ }^{3}$
}

\author{
Simone Vilas Trancoso Souza ${ }^{2}$
}

\begin{abstract}
BACKGROUND: Knowledge of the relationship between specific geographical differences and histopathology of the American cutaneous leishmaniasis is limited because host-parasite interactions in space and time are complex.

OвJеCтIV: To describe the geographic analysis of the histopathological pattern of localized American cutaneous leishmaniasis and the relationship with Leishmania species.

METHODS: A cross-sectional, descriptive and analytical study of a sample consisting of 55 patients of municipal districts of Montes Claros and 32 of Caratinga, Minas Gerais, by comparing with other endemic regions in Brazil, assessing historical and microregional data and developing confidence intervals. REsulTs: A preponderance of cellular exudative reactions in the cutaneous form of American cutaneous leishmaniasis was found in the municipal districts of Caratinga, east of Minas Gerais, Montes Claros, north of Minas Gerais and Uberlândia, Triangulo Mineiro, and also in the states of Mato Grosso and Ceara. Necrotic and exudative granulomatous reactions were found to be more frequent in the northern areas, mainly in the states of Amazonas and Para. Necrotic and exudative reactions were the most frequent form of presentation found throughout Brazil when the predominance of $L$. braziliensis was below $90 \%$ in relation to other species.

Conclusion: There is a geographic variation of the immune inflammatory response in American cutaneous leishmaniasis. Geographical correlations between the predominant species of Leishmania and the most frequent forms of histopathological presentation of American cutaneous leishmaniasis, which until the present study had not been performed, enables new approaches to the study of Leishmania subpopulations in areas with a predominance of one species and provides evidence of variations in the biological behavior of different species.

Keywords: Geography; Leishmaniasis, cutaneous; Pathology; Skin
\end{abstract}

Resumo: Fundamentos: O conhecimento das relações entre diferenças geográficas específicas e a histopatologia da leishmaniose tegumentar americana é limitada devido à complexidade espacial e temporal da interação hospedeiro-parasito.

OBjETIVos: Descrever a distribuição geográfica do padrão histopatológico da leishmaniose tegumentar americana na forma cutânea localizada e a relação com a espécie de Leishmania.

Ме́тоDоs: Estudo transversal, descritivo e analítico, de uma amostra de 55 pacientes de Montes Claros e 32 de Caratinga, Minas Gerais, comparando com diferentes regiões do Brasil através de avaliações históricas, microregionais e da construção de intervalos de confiança.

REsultados: Na forma cutânea da leishmaniose tegumentar americana, foi encontrada uma preponderância de reações exsudativas-celulares nos municípios de Caratinga, leste de Minas Gerais, Montes Claros, norte de Minas Gerais e Uberlândia, Triângulo mineiro, e também nos estados de Mato Grosso e Ceará. As reações exsudativas-necróticas-granulomatosas encontradas foram mais freqüentes em áreas do norte do Brasil, principalmente nos estados do Amazonas e Pará. As reações exsudativas-necróticas foram as formas mais freqüentes de apresentação encontradas em todas as áreas no Brasil quando a predominância de L. braziliensis foi menor que 90\% em relação às outras espécies.

ConclusõEs: Existe uma variação geográfica da resposta inflamatória imune na leishmaniose tegumentar americana. As correlações geográficas entre as espécies predominantes de Leishmania e o espectro histopatológico da leishmaniose tegumentar americana, que até que o presente estudo não tinha sido realizada, permite novas abordagens nos estudos de subpopulações de Leishmania em áreas com uma predominância de uma espécie e provê evidência das variações no comportamento biológico de diferentes espécies.

Palavras-chave: Geografia; Leishmaniose cutânea; Patologia; Pele

Received on 30.03.2011

Approved by the Advisory Board and accepted for publication on 25.07.2011.

* Work performed at the Post-graduation Program in Health Sciences of the Universidade Estadual de Montes Claros (UNIMONTES) - Montes Claros (MG), Brazil. Conflict of interest: None

Financial funding: None

Master in Health Sciences - Researcher Professor - Center for Research in Infectious Diseases - Hospital Universitário Clemente Faria - Universidade Estadual de Montes Claros (HUCF - UNIMONTES) - Montes Claros (MG), Brazil.

Specialist - Designated Professor - Universidade Estadual de Montes Claros (UNIMONTES) - Montes Claros (MG), Brazil.

Post-Doc in Parasitology - Professor - Post-graduation Program in Health Sciences of the Universidade Estadual de Montes Claros (UNIMONTES) - Montes Claros (MG), Brazil.

(C)2012 by Anais Brasileiros de Dermatologia

An Bras Dermatol. 2012;87(3):369-74. 


\section{INTRODUCTION}

The essential characteristic of the ACL pathology is the colonization of the mononuclear phagocytic system cells by amastigotes resulting in a granulomatous inflammatory response. The granuloma is defined as a compact collection of mature mononuclear phagocytes, not necessarily accompanied by accessory characteristics like necrosis. Although the histological presentation of the ACL shows a great variability, a predominant pattern characterized by the presence of disorganized granuloma without necrosis is very common and could be related to species and subspecies of Leishmania. ${ }^{1,2}$ However, the knowledge of the relationship between specific geographic differences and the histopathology of the ACL is limited due to a complex spatial and temporal host-parasite interaction. Besides this, another complicating aspect is the fact that histopathological patterns can be different within the same lesion, depending on its duration. ${ }^{1}$

The American cutaneous leishmaniasis presents with a spectrum of clinical and histological manifestations. The value of the histological exam on the diagnosis of ACT is established and different patterns of reactions, related to the duration and the clinical type of the lesion are reported, but the correlation has not been consistent. ${ }^{1,2}$ Therefore, the level of heterogeneity of Leishmania in the same endemic area and the association with biologic characteristics require a more detailed investigation. The literature has shown evidence that the Leishmania braziliensis is composed by sub-populations of parasites with specific biochemical and immunologic characteristics, and it is possible that these subpopulations could cause the differences in the histopathological spectrum. ${ }^{3}$

Finding out the Brazilian geographic limits of the ACL histopathological spectrum facilitates the assessment of the biologic behavior of the Leishmania in relation to the hosts' response. Geographic correlation through the analysis of the predominant species of Leishmania and the most frequent histopathological pattern within the ACL spectrum, which had not been done until now, will be able to provide new approaches to the study of subpopulations of the parasite in areas with a predominance of one species, as well as evidence the variations of the biologic behavior of different species.

\section{MATERIAL NAD METHODS}

Cross-sectional, descriptive and analytical study of a convenience sample of biopsy cuts, encased in paraffin and stained by hematoxylin-eosin, from skin lesions of 55 patients from Montes Claros collected during the period of 2002 to 2006 and 32 from Caratinga, Minas Gerais (MG), collected during the period of 1996 to 1998, comparing with different regions of Brazil through historic and micro-regional evaluations found on the literature, enabling the construction of maps which observe the variations of the histopathological pattern correlating factors from the parasite with the natural dynamics of ACL. For the historic histological and morphological evaluation and the comparative geographical analyses of the species and subspecies of Leishmania (identified by PCR) research in indexed publications as well as contact with university libraries and research centers in order to access thesis and dissertations not electronically available were carried out. Comparative histopathological and historical evaluations of regions from the state of de Minas Gerais for the observation of interactions between the predominant species and the host response in complex and encompassing geographical areas were performed. The main limitation was the historical diversity of the histological and morphological classifications found in the literature and in order to correct it this study observed the classification and comparative analyses of the histopathological pattern as proposed by Bittencourt \& Barral. ${ }^{1}$ The histopathological alterations found in ACL lesions were defined in three patterns of inflammatory reactions: 1. Exudative-cellular reaction (ECR) - inflammatory infiltrate with plasmocytes, macrophages and lymphocytes in the absence of epithelioid or gigantic cells; 2 . Exudative-necrotic reaction (ENR) - disorganized granulomatous infiltrate with epithelioid cells; 3 . Granulomatous exudative-necrotic reaction (GENR) presence of tuberculoid granulomas. Study approved by the Ethics Committee of the Universidade Estadual de Montes Claros under the number 2054/10. The statistical analysis was performed by constructing $95 \%$ confidence intervals for the proportion of patients with ACL according to the histopathological pattern.

\section{RESULTS}

In the localized cutaneous form of ACL there is a preponderance of ECR in the cities of Caratinga, east of MG, Montes Claros, north of MG, Uberlândia, triângulo mineiro, which is similar when compared to the states of Mato Grosso and Ceará (Figure 1)..-8 Exudative-necrotic reaction is more frequent on the north of Brazil, especially in the states of Amazonas and Pará. 9,10 Granulomatous reactions (ENR/GENR) are more frequent in all the states of Brazil, except for Ceará, Minas Gerais and Mato Grosso (Figure 2). The analysis found statistically significant differences among the Brazilian regions with a preponderance of the diffuse infiltrate histopathological pattern (ECR) in relation to the regions with a predominance of the granulomatous infiltrate (Table 1). ${ }^{2,6,7,9-14}$ 


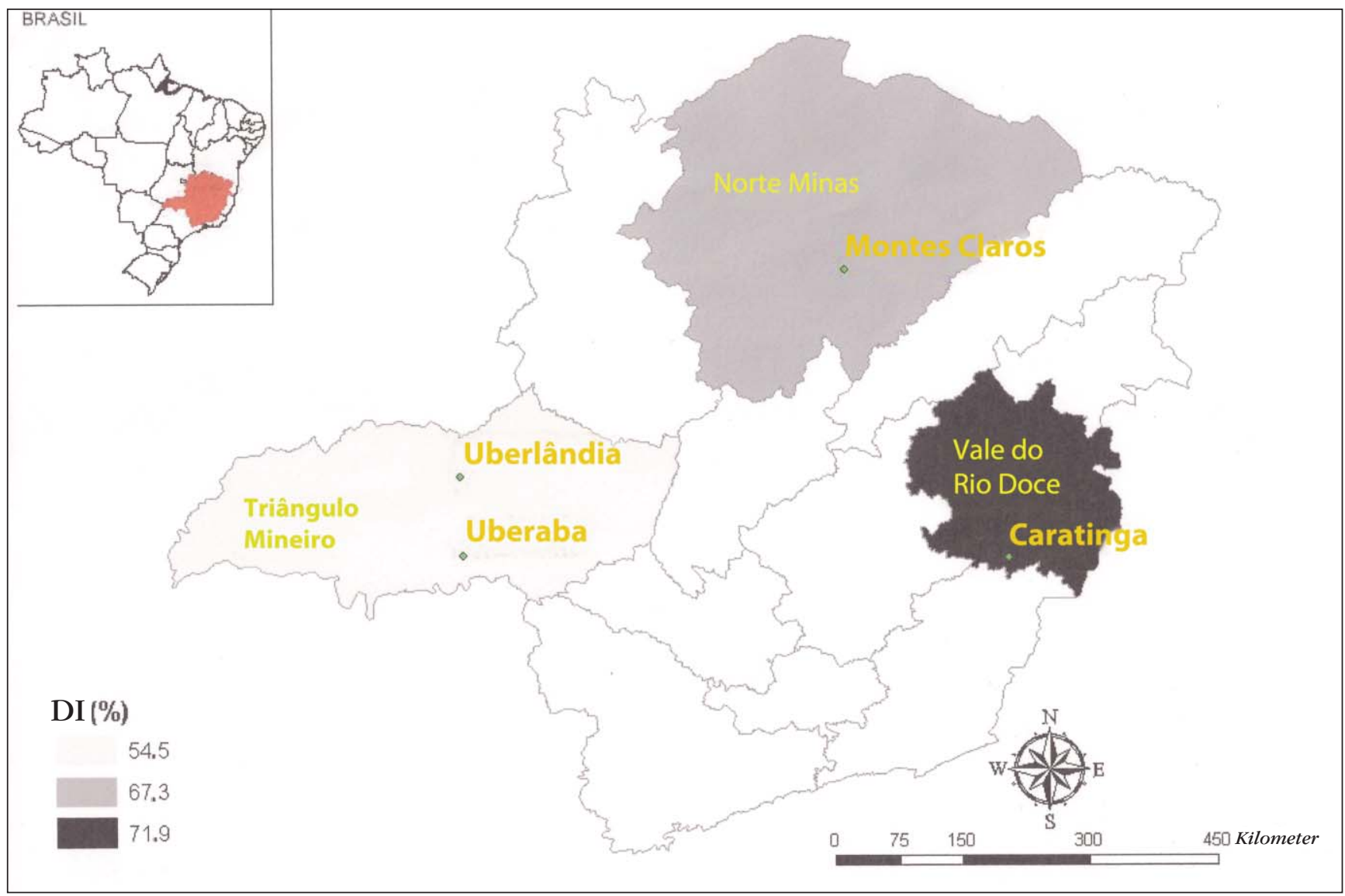

FIGURE 1: Relative frequency of diffuse infiltrate (DI= exudative-cellular reaction) in patients with American cutaneous leishmaniasis in micro-regions of the state of Minas Gerais

In Brazil, the predominant species in the localized cutaneous form of ACL is the braziliensis. When the predominance of this species is over $90 \%$, ECR is the most frequent histopathological pattern, like in Minas Gerais, Mato Grosso and Ceará, which indicates a smaller granulomatogenic activity in these regions. ${ }^{15 \cdot 17}$ When the predominance is under $90 \%$ in relation to other species, the most frequent pattern is the ENR, as in the states of Amazonas, Bahia and São Paulo (Figure 3). ${ }^{11-14,18-}$ ${ }^{27}$ There is a inversely proportional relationship between Leishmania braziliensis and the granulomatous histopathological pattern, demonstrated by a smaller presence of $L$. braziliensis and a higher occurrence of granulomatous infiltrates (disorganized or tuberculoid), which reflects in a higher frequency of tuberculoid infiltrate in regions of the Pontal do Paranapanema, São Paulo, with a $75 \%$ predominance of $L$. braziliensis and in the state of Para, with $71.8 \%$ predominance of the L. braziliensis complex.

\section{DISCUSSION}

It is well known that there is a clinical and histological spectrum in ACL. The spectrum and its vari- ations are dependent on many factors, such as the type and the duration of the clinical lesions, the species and subspecies of the parasite, the geographic location, the parasite load and the host response. In a study of the progress of the lesions, the authors confirmed that the ECR histological pattern constitutes both the initial and the final aspects of the lesion, influencing their regression or progression, and that the presence of the granulomatous pattern limits the number of lesions, making them more superficial with a better prognosis. ${ }^{2}$ However, other authors demonstrated the presence of more than one histopathological pattern in the same lesion and that these patterns do not represent the stage of the disease which be correlated with prognosis or therapeutic response. ${ }^{1}$ On the other hand, there is evidence showing that the disease caused by the Leishmania braziliensis is different from the one from other complexes due to the smaller number and higher diameter of the lesions and the association with adenomegaly, distinct from the Leishmania guyanensis which causes a clinical condition characterized by smaller and more numerous lesions. ${ }^{28}$ Besides, it has been reported that a sub- 


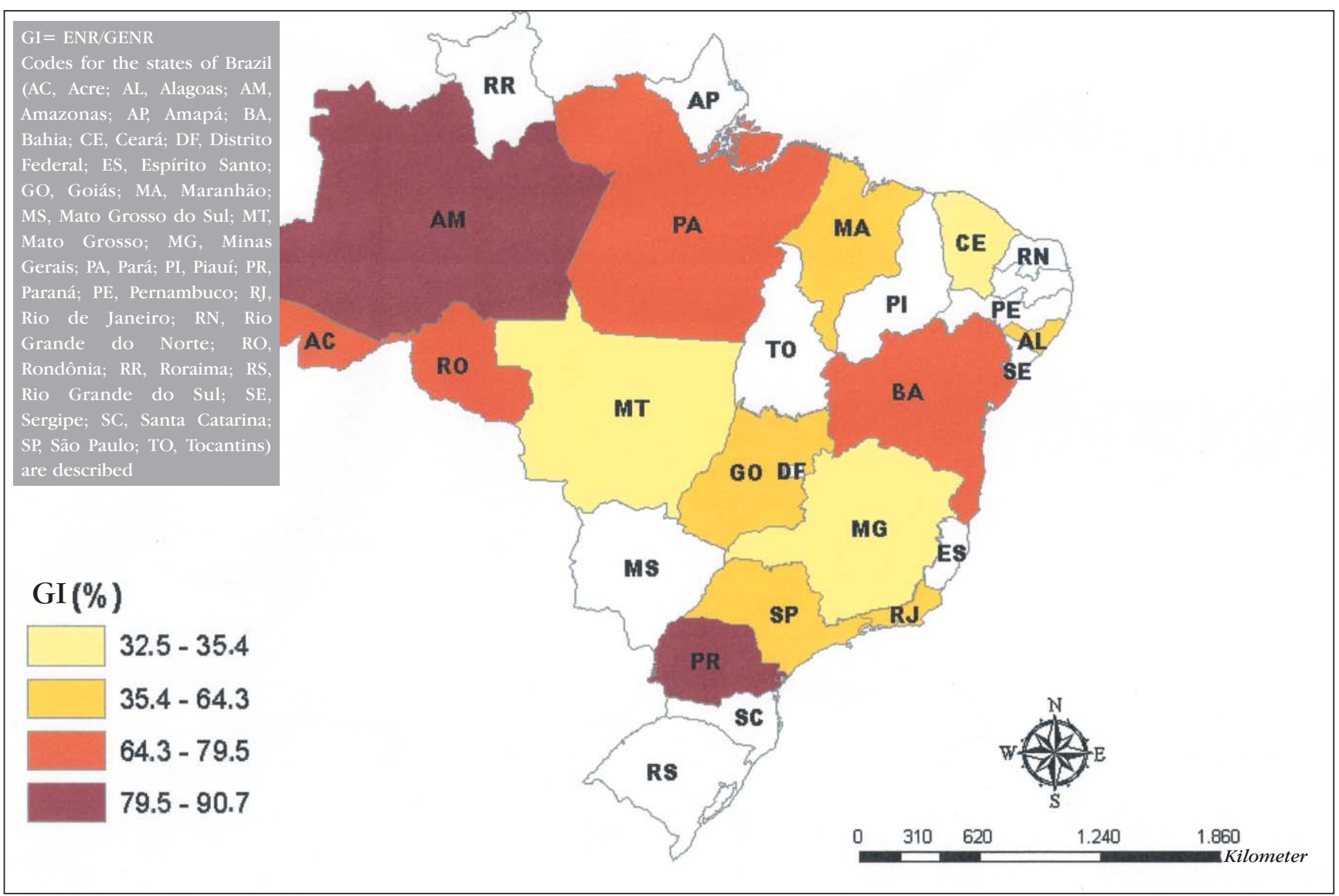

FIGURE 2: Relative frequency of granulomatous infiltrate (GI) in patients with American cutaneous leishmaniasis in the various states of Brazil

TABLE 1: Confidence intervals for the proportion of patients with American cutaneous leishmaniasis according to histopathological pattern in different micro-regions of Brazil

\begin{tabular}{|c|c|c|c|c|c|c|c|}
\hline \multirow{2}{*}{$\begin{array}{l}\text { Histopathological } \\
\text { pattern } \\
\text { Regions }\end{array}$} & \multicolumn{3}{|c|}{ Diffuse infiltrate } & \multicolumn{3}{|c|}{ Granulomatous infiltrate } & \multirow[t]{2}{*}{ Study year } \\
\hline & $\mathbf{n}^{\mathbf{o}}$ & $\%$ & CI95 & $\mathbf{n}^{\mathbf{o}}$ & $\%$ & CI95 & \\
\hline Cariri - CE* & 43 & $(67,2)$ & $0,58-0,76$ & 21 & $(32,8)$ & $0,24-0,42$ & 2002 \\
\hline Cuiabá - MT* & 45 & $(67,2)$ & $0,58-0,76$ & 22 & $(32,8)$ & $0,24-0,42$ & 2002 \\
\hline Parati - RJ* & 20 & $(62,5)$ & $0,53-0,72$ & 12 & $(37,5)$ & $0,28-0,47$ & 2008 \\
\hline \multicolumn{8}{|l|}{ North of } \\
\hline Minas - MG* & 37 & $(67,3)$ & $0,58-0,77$ & 18 & $(32,7)$ & $0,24-0,42$ & 2010 \\
\hline Vale do Rio Doce - MG* & 23 & $(71,9)$ & $0,63-0,81$ & 09 & $(28,1)$ & $0,29-0,37$ & 2010 \\
\hline Belém - PA** & 06 & $(27,3)$ & $0,19-0,36$ & 16 & $(72,7)$ & $0,64-0,81$ & 1982 \\
\hline Maceió - AL** & 08 & $(38,1)$ & $0,29-0,48$ & 13 & $(61,9)$ & $0,52-0,71$ & 2006 \\
\hline Manaus - AM** & 19 & $(21,8)$ & $0,14-0,30$ & 68 & $(78,2)$ & $0,70-0,86$ & 2007 \\
\hline Ribeirão Preto - SP** & 26 & $(48,1)$ & $0,38-0,58$ & 28 & $(51,9)$ & $0,42-0,62$ & 2002 \\
\hline Rio de Janeiro - RJ** & 04 & $(21,1)$ & $0,13-0,29$ & 15 & $(78,9)$ & $0,71-0,87$ & 2008 \\
\hline Três Braços - BA** & 140 & $(44,6)$ & $0,35-0,54$ & 174 & $(55,4)$ & $0,46-0,65$ & 1986 \\
\hline
\end{tabular}

* mid-regions with predominance of diffuse infiltrate

** mid- regions with predominance of granulomatous infiltrate

CI95 $=95 \%$ confidence interval

Codes for the states of Brazil (AL, Alagoas; AM, Amazonas; BA, Bahia; CE, Ceará; Mato Grosso; MG, Minas Gerais; PA, Pará; PR,

Paraná; RJ, Rio de Janeiro; SP, São Paulo; CE, Ceará) are described. 


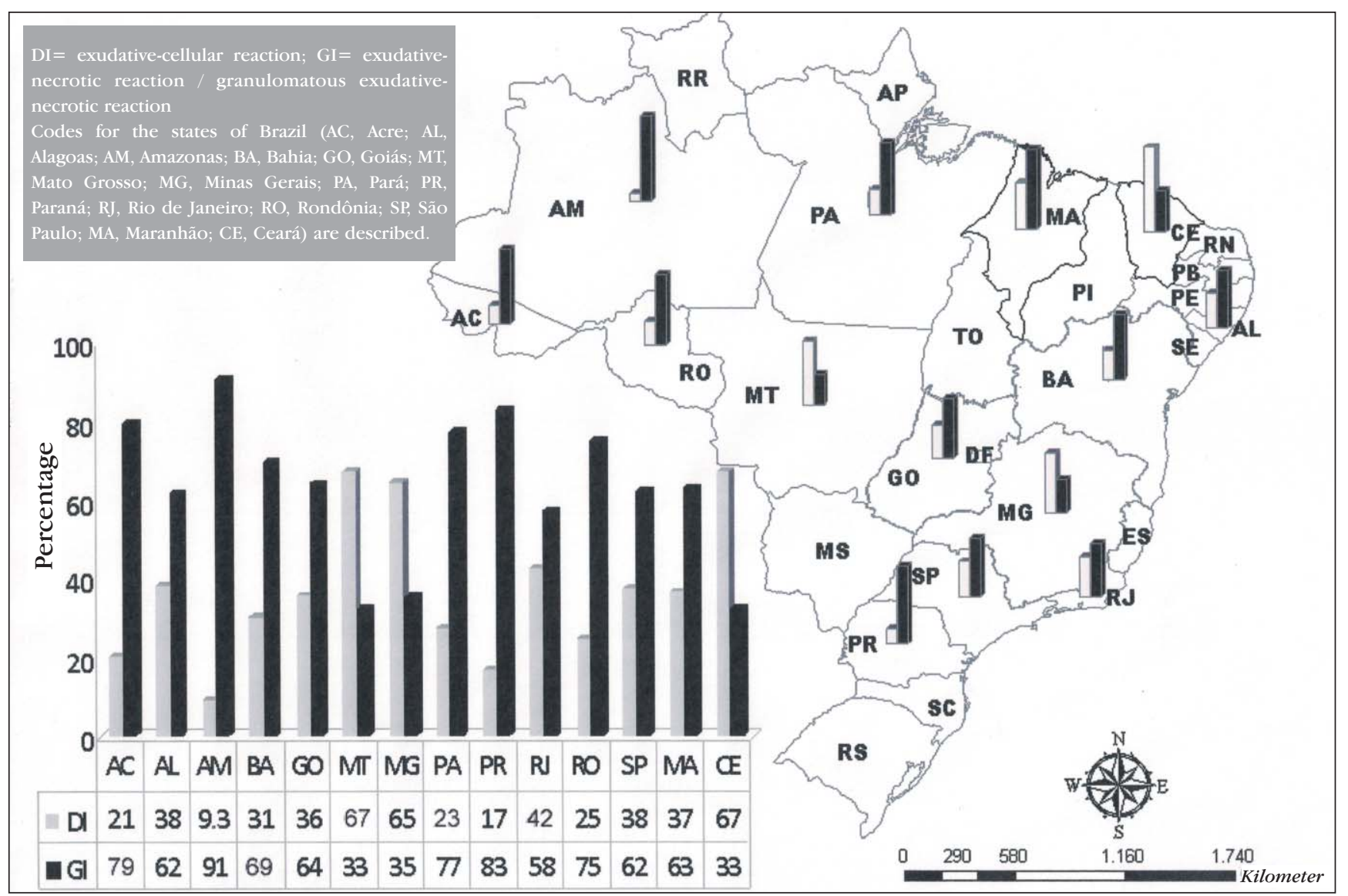

Figure 3: Percentage of diffuse infiltrate (DI); and granulomatous infiltrate (GI) in patients with American cutaneous leishmaniasis in the various states of Brazil

population of L. braziliensis in the state of Ceará (with almost absolute prevalence of this species and predominantly ECR) is more pathogenic than the subpopulation found in the state of Bahia (predominantly ENR), causing bigger lesions, high ganglionic involvement and higher persistence of the parasite. 3 This study confirms that the main etiological agent, $L$. braziliensis, as well as its subpopulations, has a lower granuloma formation activity, which could be related to the geographic distribution of ACL, promoting a predisposition to a variety of histopathological patterns and consequently the different classifications proposed in the literature. In this context, the study of the microenvironment of the lesion according to the cellular pattern, its distribution and inter-relations, as well as the determination of inflammatory markers can contribute to the understanding of the local dynamics of the immune response. ${ }^{3,12}$ As if the aggregated assessment of the differences in the geographic distribution of the histopathological spectrum of ACL can contemplate the histological variations in a effective manner, it will be a challenge to be overcome over the next years. ${ }^{29,30}$

\section{CONCLUSION}

The geographic correlations among the predominant species of Leishmania and the histopathological spectrum of ACL, which until the present study had not been done, enables new approaches to the study of subpopulations of Leishmania in areas with a predominance of one species and foresees evidence of variations of the biological behavior of different species. This study concludes that there is a geographic variation of the inflammatory immune response of ACL, and suggests that new studies might elucidate the predominance of the exudative-cellular reaction histopatholohical pattern in some regions in relation to the preponderance of granulomatous reactions in others, providing subsides for the understanding of the performance of granulomatous agents implicated in pathology of ACL. 


\section{REFERENCES}

1. Bittencourt AL, Barral, A. Evaluation of the histopathological classifications of American Cutaneous and mucocutaneous Leishmaniasis. Mem Inst Oswaldo Cruz. 1991;86:51-56

2. Magalhães AV, Moraes MAP, Raic NA, Llanpos-Cuentas EA, Costa JML, Cuba-Cuba $\mathrm{CA}$, et al. Histopatologia da Leishmaniose Tegumentar por Leishmania braziliensis braziliensis. Padrões histopatológicos e estudo evolutivo das lesões. Rev Inst Med Trop. 1986;28:253-62.

3. Teixeira MJ. Cepas de Leishmania braziliensis com perfis genômicos diversos induzem processos inflamatórios diferentes em camundongos Balb/C [tese]. Salvador (BA): Universidade Federal da Bahia; 2005.

4. Araújo NS, Machado Ml, Rocha A, Cury MCC. Aspectos clínicos e histopatológicos da leishmaniose tegumentar americana em pacientes atendidos no hospital de clínicas da Universidade Federal de Uberlândia, MG, Brasil. Rev Patol Trop. 2008;37:23-31.

5. Machado MI, Nishioka SA, Ferreira MS, Costa-Cruz JM, Rocha A, Silva AM, et al. Leishmaniose Tegumentar Americana no Triangulo Mineiro e Alto Paranaiba, Minas Gerais, Brasil: aspectos clinico-laboratoriais e epidemiológicos de uma microepidemia. Rev Cent Cienc Biomed Univ Fed Uberlândia. 1992;8:17-28.

6. Carvalho MLR, Fontes CJF, Hueb M, Guedes AM, Afonso LCC, Melo MN Leishmaniose tegumentar no Estado de Mato Grosso: estudo clínico, laboratorial e terapéutico. An Bras Dermatol. 2002;77:45-56.

7. Silva CGL. Apresentação e avaliação de aspectos clínicoepidemiológicos e histopatológicos em pacientes com leishmaniose tegumentar americana (LTA), forma ulcerada, provenientes de áreas endêmicas da região do Cariri [dissertação]. Fortaleza (CE): Universidade Federal do Ceará; 2002.

8. Silva JCF. Leishmaniose tegumentar americana (LTA), nos municípios do Crato Juazeiro do Norte e Barbalha, Estado do Ceará, Brasil, 2003-2005 [dissertação]. Fortaleza (CE): Universidade Federal do Ceará; 2008.

9. Andrade RV. Reação em cadeia de polimerase em biópsias de pele emblocadas em parafina compatíveis com leishmaniose tegumentar Americana [dissertação]. Manaus (AM): Universidade do Estado do Amazonas; 2007.

10. Brito AC. Aspectos histopatológicos da leishmaniose tegumentar americana. An Bras Dermatol. 1982;57:145-6.

11. Duarte ML, Rochael MC. Perfil histopatológico e imuno-histoquímico da leishmaniose tegumentar americana com ênfase nos dendrócitos dérmicos FXIIla+. An Bras Dermatol. 2006;81:541-8.

12. Morgado FN, Schubach A, Rosalino CM, Quintella LP, Santos G, Salgueiro M, et al. Is the in situ inflammatory reaction an important tool to understand the cellular immune response in American tegumentary leishmaniasis? Br J Dermatol. 2008;158: 50-8.

13. Vieira-Gonçalves R, Pirmez C, Jorge ME, Souza WJ, Oliveira MP, Rutowitsch MS, et al. Clinical features of cutaneous and disseminated cutaneous leishmaniasis caused by Leishmania (Viannia) braziliensis in Paraty, Rio de Janeiro. Int J Dermatol. 2008;47: 926-32

14. Medeiros ACR, Rodrigues SS, Roselino AMF. Comparison of the specificity of PCR and the histopathological detection of Leishmania for the diagnosis of American cutaneous leishmaniasis. Braz J Med Biol Res. 2002;35:421-4.

15. Passos VM, Fernandes O, Lacerda PA, Volpini AC, Gontijo CM, Degrave W, et al Leishmania (Viannia) braziliensis is the predominant species infecting patients with American cutaneous leishmaniasis in the state of Minas Gerais, Southeast Brazil. Acta Trop. 1999;72:251-8.

16. Carvalho ML, Andrade AS, Fontes CJ, Hueb M, Oliveira Silva S, Melo MN. Leishmania (Viannia) braziliensis is the prevalent species infecting patients with tegumentary leishmaniasis from Mato Grosso State, Brazil. Acta Trop. 2006;98:277-85.

17. Sousa $A Q$, Pearson R. Drought, smallpox and emergence of Leishmania braziliensis in northeasten Brazil. Emerg Infect Dis. 2009;15:916-21.

18. Jennings YLL. Caracterização isoenzimática e por anticorpos monoclonais dos agentes da Leishmaniose Tegumentar Americana (LTA) na mesorregião do Baixo Amazonas, Estado do Pará, Brasil [dissertação]. Belém (PA): Universidade Federa do Pará; 2003.
19. Barral A, Pedral-Sampaio D, Grimaldi Júnior G, Momen H, McMahon-Pratt D, Ribeiro de Jesus A, et al. Leishmaniasis in Bahia, Brazil: evidence that Leishmania amazonensis produces a wide spectrum of clinical disease. Am J Trop Med Hyg. 1991:44:536-46.

20. Garcia FCB, Santos SSR, Chociay F, Medeiros ACR, Roselino AMF. Métodos subsidiários para o diagnóstico da Leishmaniose tegumentar americana (LTA): comparação dos resultados do seqüenciamento de DNA e da PCR-RFLP para determinação da espécie de leishmania em amostras cutâneo-mucosas. An Bras Dermatol. 2005;80(Suppl 3): S339-44

21. Alessi CAC. Leishmaniose cutânea americana no Pontal do Paranapanema - SP: avaliação clínica, histopatológica e uso da reação em cadeia da polimerase (PCR) para identificação e caracterização das espécies de Leishmania [tese]. São Paulo (SP): Universidade de São Paulo; 2007.

22. Furtado VMG. Imunofenotipagem em leishmaniose cutânea [dissertação]. Brasília (DF): Universidade de Brasília; 2006.

23. Motta JOC. Estudo comparativo da resposta imunológica e clínica entre a Anfotericina B lipossoma e a N-metil glucamina em pacientes com a forma localizada da leishmaniose tegumentar americana (LTA) [dissertação]. Brasília (DF): Universidade de Brasília; 2006.

24. Couto MJAA. Leishmaniose tegumentar no Maranhão. Estudo histopatológico e imunoistoquímico da forma difusa da doença [dissertação]. Brasília (DF): Universidade de Brasília; 2004

25. Lunedo SC. Imunocitoquímica e imunoistoquímica para o diagnóstico de LTA [tese] Curitiba (PR): Universidade Federal do Paraná; 2007.

26. Corrêa EA. Aspectos epidemiológicos e clínico-laboratoriais da leishmaniose tegumentar americana nos subespaços 07 e 08 no Estado de Rondônia - Brasil [dissertação]. Brasília (DF): Universidade de Brasília; 2007.

27. Cucé LC, Freitas THP, Oliveira ZNP, Sampaio SAP. Tratamento da leishmaniose tegumentar americana pelo antimônio pentavalente (esquema rápido). An Bras Dermatol. 1982;57:107-8.

28. Romero GA, Vinitius De Farias Guerra M, Gomes Paes M, de Oliveira Macêdo V. Comparison of cutaneous leishmaniasis due to Leishmania (Viannia) braziliensis and L. (V.) guyanensis in Brazil: clinical findings and diagnostic approach. Clin Infect Dis. 2001;32:1304-12.

29. Botelho ACC, Tafuri WL, Genaro 0, Mayrink W. Histopathology of human american cutaneous leishmaniasis before and after treatment. Rev Soc Bras Med Trop. 1998 31:11-8.

30. 30. Novais FO, Santiago RC, Báfica A, Khouri R, Afonso L, Borges VM et al. Neutrophils and macrophages cooperate in host resistance against Leishmania braziliensis infection. J Immunol. 2009;183:8088-98.

\author{
MAILING ADDRESS: \\ Linton Wallis Figueiredo Souza \\ Av. Cula Mangabeira, 562 \\ Montes Claros Minas Gerais, MG \\ 39401-001 \\ E-mail:wallis@uai.com.br
}

How to cite this article: Souza LWF, Souza SVT, Botelho ACC. Comparative analysis of the geographic distribution of the histopathological spectrum and Leishmania species of American cutaneous leishmaniasis in Brazil. An Bras Dermatol. 2012;87(3):369-74. 